\title{
Seksualitet som øloplukker \\ - en samtale om dansk seksualitetsforskning
}

\section{RUNDBORDS- SAMTALE}

$\Gamma_{\text {efteråret } 2008 \text { inviterede }}$

Kvinder, Kon es Forskning og Gefion - Feministisk Netverk til en rundbordssamtale om dansk seksualitetsforskning $i$ primart et humanistisk perspektiv. De inviterede forskere beskaftiger sig alle med seksualitet på den ene eller anden maide $i$ deres forskning. Denne aften var de inviteret til at snakke om potentialer og perspektiver $i$ at arbejde med seksualitet. Det blev til en spendende aften om Foucault og Butler, psykoanalysens tilbagekomst, queer teori og feminisme, det danske frisind og seksualitet som analysekategori og identitet.

De inviterede forskeve var Maja Bissenbakker Frederiksen, ph.d., undervisningsassistent, Københavns Universitet, Lene Myong Petersen, ph.d.-stipendiat ved Danmarks Pedagogiske Universitetsskole, Arhus Universitet, Peter Edelberg, ph.d.-stipendiat, Københavns Universitet og Bente Rosenbeck, lektor, Københavns Universitet. Ordstyrer var Mathias Danbolt, ph.d.-stipendiat ved Universitetet $i$ Bergen. Nedenstaiende er et redigeret uddrag af samtalen. 
Mathias: Hvordan opererer begrebet seksualitet i hvert jeres forskningsunivers?

Maja: Jeg ser ikke umiddelbart mig selv som seksualitetsforsker, men som magtanalytiker der har fokus på den her sære størrelse, som hedder seksualitet. Jeg ser det ikke så meget som et fænomen, men som en effekt ved de forskellige magtdiskurser. Noget der kan give sig udslag i f.eks. litteratur eller danskfaget. For at bruge Sedgwicks ord så er seksualitet et område, som vi altid må holde åbent. Seksualitet er først og fremmest interessant som en projektionsflade for en masse andre sociale kategorier og forståelser - mere end som en ting i sig selv, som man kan undersøge.

Lene: Det, som jeg er i gang med at skrive ph.d. om, er transnational adoption. Det er et kvalitativt studie, hvor jeg interviewer en række voksne adopterede. Så jeg ser heller ikke mig selv som seksualitetsforsker, men seksualitet indgår i mit projekt, idet jeg har spurgt mine informanter om f.eks. datingformer og forskellige former for intimitet. Det, der er min interesse, er, hvordan seksualitet intersektionaliserer med etnicitet og race og køn. Dvs. at udvide forståelsen af seksualitet som noget der ikke kun handler om køn, men også race og etnicitet.

Peter: Så er jeg måske mere traditionel seksualitetsforsker, for jeg er historiker og forsker i homoseksualitetens historie, sådan som den konkret har udspillet sig. Der er ikke skrevet særlig meget om, hvordan homoseksualiteten har udformet sig i Danmark i det 20. århundrede. Der er kun et par artikler om de konkrete store begivenheder, som f.eks. at homoseksualitet blev afkriminaliseret i 30'erne. Når vi forsøger at skrive homoseksualitetens historie i Danmark, refererer vi straks til USA, til Stonewall i 1969, til AIDS-krisen i 80'erne, som udspiller sig meget anderledes i USA, til ACT UP og queer aktivismen i 80'erne og 90 'erne. Men danskerne havde diskuteret homoseksualitet lang tid før Stonewall i forbindelse med den såkaldt 'grimme lov' i starten af 60'erne, som var en lov mod homoprostitutionskunder. Den danske historie er ikke lig med den amerikanske, og det vil jeg meget gerne vise - hvad var de afgørende elementer i den danske historie.

Bente: Jeg vil også starte som historiker med lidt historiografi: da jeg for mange år siden skulle formulere mit forskningsprojekt, hed det Kvinder i privatsfaren: fertilitet og seksualitet. Og det opfattede jeg sådan set som meget vovet dengang - både i forhold til 'the establishment' og i forhold til kønsforskningen, som dengang et par år før 1980 var meget arbejdsmarkeds- og produktionsorienteret. Men der var begyndt at komme gang i seksualitetsforskningen i Danmark. Jeg fandt lige en lille artikel, jeg skrev i 1983, som hedder Seksualitetsforskning - en kort oversigt. Og den var såmænd meget kort - jeg nævner kun to: Wilhelm von Rosen, som er den, der har opdyrket den historiske homoseksualitetsforskning i Danmark, og Karin Lützen, som havde skrevet en artikel i det, der på det tidspunkt hed Kvindestudier. Det var den danske forskning. Derudover var der selvfølgelig Foucault og alle de teoretikere, som benyttede ham. I Danmark var vi i den specielle situation, at vi havde en Foucaultfortolker, nemlig Esben Krause-Jensen, som meget tidligt oversatte Foucaults værker og som ikke var bange for at oversætte Seksualitetens historie. Og når jeg siger ikke bange, så er det fordi, jeg gennem årene har set mange, som er inspirerede af Foucault, men de læste ligesom udenom Seksualitetens historie. Den var på en måde for provokerende og fræk - men det var den altså ikke for Esben Krause-Jensen, der også oversatte interviews med Foucault. Introduktionsbindet til Seksualitetens historie udkom i Danmark to år efter, den var kommet på fransk. Ellers tror jeg ikke, den ville være blevet så stor en inspirationskilde for det, jeg lavede. 
Peter: Foucault har også været en kæmpe inspiration for mig. Jeg er nok mere med på 'den anden bølge', som i høj grad har været tegnet af Dag Heede og hans bog om Foucault. Da jeg var i Landsforeningen for Bøsser og Lesbiskes ungdomsgruppe, blev man skrevet ind i en historie, der startede med Stonewall i New York, og derfor var det en kæmpe inspiration at læse Foucault og få den historie vendt på hovedet: at det ikke kun har handlet om undertrykkelse. Hele omvendelsen af repressionshypotesen - man skal ikke se det hele som repression, men også at der er forskellige typer homoseksualitet.

Bente: Man er tilbøjelig til at sige, at det hele startede i USA, men jeg vil sige, at det på mange måder startede i Europa - ikke mindst i Holland. I 80'erne var forskningen meget sociologisk orienteret - modsat i 90 'erne hvor den bliver mere litterær. Det var engelske forskere som bl.a. Mary McIntosh, Jeffrey Weeks og Kenneth Plummer, som satte dagsordenen, men der kom også amerikanske forskere på europæiske konferencer, bl.a. Lillian Federman. Og så sker der et brud omkring 1990 med queer. Inden da var diskussionen bundet op på essens versus konstruktion, men det kom vi videre fra med Judith Butler og andre. Der er dog ikke tale om et totalt brud. Jeg synes også, der var en vis kontinuitet. 80 'ernes arbejde med seksualitet handlede om homoseksualitet. Det var homoseksualitet, der var en konstruktion, som skulle studeres. I 90'erne var det heteroseksualitet, der blev set som en konstruktion, der skulle undersøges. Foucault er også til stede i queer som en genopdagelse. Don Kulick stod i en sølvsmoking på et seminar i Umeå og skulle udbrede det glade nye budskab om queer, og da han så skulle svare på, hvad det nye var, så var det Foucault. Men det nye er bl.a., at Butler tager højde for Foucaults manglende kønsblik, så hun fusionerer seksualitet og køn. Og det ser jeg også i de nyere analyser som f.eks. Majas. Det er på en måde en slags mainstreaming af køn og seksualitet. Man analyserer noget andet, men med køn og seksualitet som kategorier, der kan åbne op for noget, i stedet for at man analyserer køn og kvinder, hetero- og homoseksualitet i sig selv. Sedgwick skriver, at man ikke kan studere en kultur uden at studere seksualiteten. Det synes jeg er en fantastisk samfundshjælper - en øloplukker til en ny måde at forstå kulturen på. Og det er det, jeg ser ske i dag.

Lene: Jeg har gået på universitetet i 90'erne, og som for mange andre er jeg kommet til spørgsmålet om seksualitet gennem den feministiske kønsforskning, og der er det i Danmark især Dorte Marie Søndergaards bog fra 1996 Tegnet på kroppen, som har været banebrydende på rigtig mange punkter. Det, som har været seksualitetsforskningens problem, er for mig at se, at det i høj grad har været hvid seksualitet, der er blevet studeret og ikke seksualitet som racialt differentieret kategori. Og her har den amerikanske forsker David Eng gjort meget, og det har været en stor inspiration.

Maja: Seksualiteten er nok sådan et forsvindingspunkt. Hvis man ser direkte på den, så forsvinder den. Man er nødt til at se på alle de der andre steder for at opdage den, og det er for mig det, der er pointen ved at læse på den måde, jeg gør. Ikke at fokusere på det seksuelle eller finde en seksuel ting, jeg så skal undersøge, men at se på andre kategorier og så se, hvordan seksualiteten spiller ind der. Det er nok den eneste måde, jeg kan se, at man rigtig kan få øje på seksualiteten. Jeg tror også, som Lene siger, at en af de helt uomgxngelige kategorier for seksualitet i de her år er racialiserede og etniske kategorier. De er så indskrevet i vores forståelse af f.eks. den repressionshypotetiske fortælling, at race og etnicitet er grundlæggende i forhandlinger af seksualitet, så vi nok ikke kan komme udenom dem. På samme måde som Sedgwick siger, at vi ikke kan analysere moderne kultur uden at se på 
seksualiteten, så er det nok spørgsmålet, om vi kan analysere seksualiteten i den moderne kultur uden at have begreber om etnicitet med. Seksualiteten er ikke een ting i sig selv. Den bliver kun til i et samspil netop mellem racialiserede kategorier. Og det er måske også derfor, Foucault har fået en renæssance. Det, som er så væsentligt ved Foucault, er, at han stillede nogle spørgsmål på en ny måde, som netop Butler og andre gik videre med at stille. Der bliver spurgt til seksualiteten på en helt anden måde end alle de gamle gjorde, bl.a. ved også at inddrage andre sociale kategorier

\section{Freud og Althusser vender TILBAGE}

Mathias: Hvor står forskningen i seksualitet i Danmark i dag, synes I? Hvad er de vigtigste spørgsmål, der bliver rejst? Hvad er de vigtigste spørgsmål, som bør rejses? Lene og Maja har været lidt inde på det i forhold til en intersektionel kobling mellem seksualitet, køn, etnicitet og race. Men hvordan ser I situationen?

Bente: Jeg synes, det er et område, hvor det er svært at være normativ, forstået på den måde, at jeg hellere vil lade de tusinde blomster blomstre. Man kan ikke vide hvad, der dukker op. Der var en konference, hvor Peter vist også var med. Den hed After Foucault. Der registrerede jeg, at psykoanalysen var på vej tilbage. Der var nogen, der mente, at der er nogle problemer, som råber på, at vi tager psykoanalysen op igen. Da David Eng var i Danmark, så mener jeg, at jeg hørte ham sige, at queer er ved at være slut i USA, og så slutter det vel også i Danmark. Jeg kan nogle gange have svært ved at se, hvordan jeg kan fă det etniske perspektiv med. Der har ikke været mange af anden etnisk oprindelse i den danske historie. Jeg ved godt, at man sagtens kan lave et kolonialt perspektiv ved også at se på, hvad vi gjorde i f.eks Indien, men ellers er det svært at se, hvordan det etniske perspektiv ligesom trænger sig på. Derimod mener jeg, at klasseperspektivet, når man ser historisk, trænger sig på, og det tror jeg også det må gøre i forhold til at studere homoseksualitet. Klasseperspektivet må være meget oplagt.

Lene: Jeg er ret interesseret i det der med psykoanalysen, der kommer tilbage. Tænker du det i en dansk kontekst, for den har jo f.eks. altid været stor i USA?

Bente: Det her var en konference i Manchester, så det var ikke en dansk kontekst. Men man kan jo se det hos en forsker som Teresa de Lauretis, som vel var Foucault-fortolker på et tidspunkt i forhold til det medie, hun arbejdede med, nemlig film. Da hun var i Sverige i 2003, og spørgsmålet lød: "Hvem vil I tage med ind i det nye årtusinde af teoretikere", så sagde hun Freud, og så blev der nærmest buhet fra salen. Og jo yngre de tilstedeværende var, jo mere blev der buhet. Det har nok ikke været den forskning, som er blomstret mest, og jeg er jo selv som historiker ikke vældig meget indlæst på psykoanalysen, men jeg tror den kommer igen. Som Freud sagde: "Hun kommer igen, den heks!”. Og det tror jeg altså også, Freud gør!

Mathias: Queer teori har jo været meget diskuteret i Norden i de seneste år, hvor psykoanalysen ikke har været italesat så meget. F.eks. taler Tiina Rosenberg, som har formidlet queer i Sverige, sjældent om Judith Butlers inspiration fra psykoanalysen. Det samme kan man vel også sige om Dorte Marie Søndergaard, som heller ikke synes interesseret i det psykoanalytiske hos Butler. Derimod er psykoanalytisk tankegods til stede i meget af den amerikanske queer teori som f.eks hos David Eng, Lee Edelman og Judith Butler. Så man kan måske sige, at da queer kom til Norden, så forsvandt psykoanalysen, og nu kommer den tilbage? 
Maja: Jeg tror, der er kommet en fornyet interesse for den. Jeg tror faktisk, det er Lilian Munk Rösing, der har kaldt queer teori for dekonstrueret Freud eller afnaturaliseret Freud. Og jeg tror, nogle af os, der er glade for Butler, begynder at se en inspiration i den mere psykoanalytiske fortælling i den forstand, at hvis man tager naturaliseringen af det psykoanalytiske væk, hvis man tager idéen om, at der er en psykisk indre essens væk, og læser Freud med Foucault, så kommer der noget ud, der nok ligner queer teorien temmelig meget. Butler er jo også, som du netop siger, meget interesseret $i$, at seksualiteten er en konstruktion, i hvordan denne konstruktion sker. Her tror jeg, at Freud har sagt en masse gode ting. Som litterat må man jo altid elske Freud, fordi han er sådan en fantastisk læser og sådan en fantastisk analytiker. Jeg tror, den der antipati mod Freudianismen, som jeg også selv har delt, måske er på vej væk. I hvert fald som instrument til at læse med. Selvfølgelig er der al heteronormativiteten og essentialismen og alt det der, som jeg synes er åndssvagt, men det kan man jo altid gå uden om.

Peter: Der er også altid det modsatte i Freud. Der er alt det antiessentialistiske og det polymorf perverse, som man altid er så glad for hos Freud. Der er så mange ting hos Freud. Det er dét, der er så spændende ved ham, synes jeg.

Lene: Jeg tror også, at psykoanalysen kommer stærkt tilbage. I Skandinavien - eller i en del af den danske, feministiske forskning - har der været en stærk tradition for netop at læse Butler uden psykoanalysen. Der tror jeg, vi vil se, at det bliver Butler med psykoanalyse i højere grad.

Bente: Der er også begrebet Melankoli, som jo er centralt hos Butler, men vel også hos nogle etnicitetsforskere. Jeg har jo registreret, hvor tydeligt det er, at man læser henover den midterste del af Gender Troub- le, som om den overhovedet ikke eksisterede. Jeg vil også nævne brugen af Althusser. Althusser er jo også en af dem, som Butler læser, men Althusser blev sådan set også læst i 70 erne, fordi han jo var marxist, og han blev læst, fordi der var nogen, der jo synes, at Marx kunne være for materialistisk og for produktionsorienteret. Én af de meget tidlige var Judith Mitchell, som allerede i 1967 skrev Women - the longest revolution, som var inspireret af Althusser. Hun brugte ham til at sige, at hvis vi ser på, hvad der er vigtigt i kvinders liv: produktion, reproduktion, avl, seksualitet, socialisering, så er det seksualiteten, der er ved at blive overdetermineret. Med det siger hun, at der sker så meget, så der sker forandring. Kvindernes position må forandre sig. Og det er en helt anden måde at fortolke Althusser på end Judith Butler gør med det begreb, der hedder interpellation, som er, hvordan vi hele tiden bliver interpelleret, hvordan vi bliver anråbt, hvordan vores identitet bliver formet af forskellige institutioner. $\mathrm{Og}$ der er gået 35-40 år imellem, og den ene fra begyndelsen af 70 erne bruger Althusser til at se forandringer, og den anden til at se hvordan vi performer vores liv. Det er den samme tekst, men den bliver altså brugt til noget forskelligt

Maja: Althusser bliver måske netop også brugt som en form for modreaktion på den anden type seksualitetsforskning, der har været, den mere Giddens-prægede "Vi gør alle sammen identiteten selv" osv. Man kan sige, det er et mindre magtanalytisk 'take' på seksualitet. Jeg tror, Althusser får en renæssance gennem behovet for at se på, hvad det er, Magten gør.

\section{FEMINISME, QUEER, SEKSUALITET}

Mathias: Hvilke teoretiske indfaldsvinkler og perspektiver er frugtbare for seksualitetsforskningen? Psykoanalysen er måske på vej tilbage, Foucault har ikke sagt sit sidste 
ord, og magtanalysen og Louis Althusser kan læses på nye måder. Er der nogle flere indgangsvinkler og perspektiver, som vi skal tage frem?

Peter: Jeg synes, at noget af det, jeg har taget fra queer teori og Eve Sedgwick, er idéen om, at der er to måder at se homoseksualitet på. Enten kan man sige, at det er noget, der ligger latent $i$ alle, og at alle er potentielt homoseksuelle, eller man kan sige, at det kun er en lille minoritet i samfundet, som er eksplicitte homoseksuelle. Det er selvfølgelig meget skarpt stillet op. Og Sedgwick siger også, at man som regel har begge systemer overlappende samtidigt, selvom det egentlig er en modsigelse. En anden, man også kan nævne i forbindelse med queer teori, er David Halperin, som har gjort opmærksom på det, der sker i slutningen af 1800-tallet, hvor man begynder at tale meget om homoseksuelle, og man ser homoseksuelle gå rundt på gaden, hvad man ikke havde set før. Mange forskellige typer af mænd; feminine mænd, mænd der godt kunne lide intime venskaber med mænd, mænd der godt kunne lide at have sex med mænd, gik hen og blev én type, som kunne forklare alt - Den Homoseksuelle. Og det, synes jeg, er et meget spændende perspektiv at se på. Når man går tilbage $\mathrm{i}$ historien, skal vi passe på ikke at tro, at vi leder efter os selv og de homoseksuelle, vi tror, vi kender i dag. Det, synes jeg, er det, som er meget interessant ved queer teori. Man åbner op for perspektivet for hvor mange forskellige sociale typer, der er indenfor homoseksualitetsbegrebet.

Maja: Jeg tror, jeg henter noget andet fra queer teori end seksualitetstyperne. Det er selvfølgelig også fordi, jeg ikke er historiker, og de analyser, jeg laver, er mere sådan samtidsorienterede. Vi har cirklet omkring det flere gange, men for mig er de interessante måder at gå til seksualitet på netop gennem andre kategorier. Klasse er f.eks. en helt uomgxngelig kategori at se på.
Den dukker op i mange forskellige diskussioner, og som Lene er inde på, er der jo også spørgsmålet om, hvordan etnisk danskhed bliver konstrueret igennem idéer om seksualitet. Det er jo ikke så meget et spørgsmål om at finde ud af, hvad for en seksualitet de andre, 'de etniske', har, men et spørgsmål om at finde ud af, hvordan idéen om etnicitet og danskhed overhovedet bliver konstrueret igennem seksualitetskategorier. Det er nok mere den krumtap, jeg tror, jeg vil bruge til at åbne det her felt. For mig er det ikke så meget en historisk analyse af de veje ad hvilke, vi er kommet til den seksualitetsforståelse, vi har nu, men at se seksualitetsforståelsen som noget, der bliver produceret nu og her, og som vi er med til at producere i politiske og sociale kontekster.

Mathias: Hvordan tænker I feltet seksualitetsforskning i forhold til feministisk forskning eller kønsforskning? Ser I begrebet seksualitetsforskning som noget andet end feministisk forskning? Som noget andet end kønsforskning?

Maja: Jeg tvivler på, at der findes én feministisk forskning. I hvert fald lægger den måde, du stiller spørgsmålet, op til - og jeg ved godt, at du gør det drilsk - at der findes en feministisk forskning, der så er kommet nogle andre forskninger, der har erstattet. F.eks. at queer teori har erstattet den feministiske forskning. Eller der er kommet en seksualitetsforskning, der så kan supplere. Men jvf. Bentes fortælling om bare de sidste 30 år, så har seksualiteten jo altid været del af den feministiske forskning, og jeg kunne ikke forestille mig en forskning, der handlede om seksualitet uden at bruge de landvindinger, som kønsforskningen allerede har gjort. Jeg ville ikke kunne forestille mig en seksualitetsforskning, der ikke handlede om køn. Det er spørgsmålet, om vi overhovedet har et begreb om seksualitet, der ikke handler om køn. Og det er spørgsmålet, om vi har en kønsforskning, 
der ikke er dybt influeret af den feministiske forskning.

Peter: Jeg tror ikke, at det jeg laver, har et særligt umiddelbart forhold til feministisk forskning. Det har et forhold til feministisk teori i den forstand, at meget af den teori, jeg arbejder med, bl.a. er Eve Sedgwick, Dave Halperin og Judith Butler, der udspringer af en feministisk tradition. Jeg arbejder med mandlig homoseksualitet i Danmark i 50'erne og 60'erne, og man kunne sikkert godt inddrage feminisme, men jeg synes ikke, det er særlig oplagt, og jeg kan ikke rigtig se, hvor man umiddelbart skulle gøre det. Men det kunne jo være, at der var nogen, der kunne komme med nogle spændende projekter om det.

Maja: Der er jeg helt uenig. Jeg ser Eve Sedgwick som først og fremmest en feministisk filosof, og jeg ser også hendes projekt som et feministisk projekt, bl.a. fordi hun siger, at de her nyvindinger eller de nye konstruktioner af seksuelle arter, der sker opfindelsen af Den Homoseksuelle - er led i nogle nye konstruktioner af, hvordan kønsroller og kønspositioner bliver fordelt i samfundet, og det ser jeg som et feministisk projekt. Selvfølgelig belyst i gennem maskulinitet og begær mellem mænd, men det er stadig et feministisk projekt, fordi det undersøger, hvordan magt bliver fordelt mellem mænd, og hvordan magt bliver fordelt mellem positioner, der har at gøre med køn. Jeg kan ikke forestille mig, at man kan tænke et homoseksualitetsbegreb, som ikke har at gøre med køn, og som ikke har at gøre med relationer mellem mænd og kvinder.

Peter: Nej, det har at gøre med køn, men det har ikke nødvendigvis at gøre med feminisme. Men jeg siger ikke, at Eve Sedgwick ikke er feminist - det er hun helt sikkert, men det jeg tager fra Eve Sedgwick er ikke primært det feministiske.
Bente: Men der kunne der måske alligevel komme noget videre ud af det i forhold til Wilhelm von Rosens analyser ved at se på mandlighed i forhold til homoseksualitet, fordi den historie jo er så meget mand. Det er næsten sådan, at de lesbiske først bliver et problem i offentligheden, i offentlige udvalg og udredninger i det øjeblik, de vil have børn. De har næsten været ikke-eksisterende helt indtil de seneste ti år. Når de vil have børn, så begynder man at tage sig af dem. Men hvis man ser på den historiske udvikling, der har været omkring homoseksualitet, og når man har haft panik af både den ene og den anden slags, så har det været mandlig homoseksualitet, så køn er jo en meget, meget tydelig kategori. Og da man i 1906 overvejer, hvad man skal gøre ved det her fænomen, så er der en jurist, der siger, at der ikke er nogen grund til at tage sig af kvinder, for det kan godt være, at de laver sådan noget, men de gør det derhjemme og ikke på offentlige gader og stræder, så glem alt om dem. Bare for at sige at køn er meget til stede, og jeg tror, det kan give et nyt perspektiv at se netop homoseksualitet i forhold til en mandlighedskategori for også at blive klogere på, hvad homoseksualitet er. Jeg tror, det vigtigste er at se fænomenet i forhold til køn, selvom det kun er mænd og mænd og atter mænd i første omgang, der presser sig på. Men når man er en majoritet ligesom med hvidhed, som Lene sagde, så har man også et køn.

\section{DET DANSKE FRISIND}

Spørgsmål fra salen: Er der nogle spørgsmål, som I kan identificere, der ikke bliver rørt ved af en eller anden årsag? Er der et eller andet i Danmark, der er tabuiseret lige nu?

Maja: Jeg tror faktisk, det er et meget godt eksempel på, hvor psykoanalysen ikke kommer igen i queer teori, eller hvor jeg ser, at der er nogle ting, vi ikke tager med, for 
som foucauldianer har jeg det utroligt svært med begrebet tabu. Og jeg ville være meget skeptisk over for at bruge begrebet tabu uden at hive hele ideen om netop forskellen mellem det, man siger, og det man ikke siger frem som et tegn på undertrykkelse eller ej. Det, Foucault har gjort, er netop at stille spørgsmålet på en ny måde. Det er spørgsmålet, om man efter Foucault har lov til at tale om tabu.

Lene: Noget af det, som jeg godt kunne tænke mig, at der blev analyseret noget mere på, det er spørgsmålet om det danske frisind. Jeg mener ikke, at det er et tabu, men jeg mener, at der bliver analyseret lidt for lidt på konstruktionen af det danske frisind. Og her spiller seksualitet jo en kæmpe rolle: hvad det er for nogle seksuelle positioner, der genereres fra det der frisind. Det er sådan noget, jeg synes kunne være rigtig interessant, hvis der blev lavet nogle analyser på.

Maja: Det handler måske ikke så meget om, hvad man ikke kan tale om, men hvad det er for nogle narrativer, man kan fortælle. Spørgsmålet er ikke, om der er ting, der er tabuiseret eller ikke italesat, men måske mere hvad for nogle fortællinger, der overhovedet kan blive genkendelige. Jeg tror, det er virkelig svært at gøre andre fortællinger genkendelige lige nu end fortællingen om det danske frisind - fortælling om seksualiteten, der bliver frigjort og sammenhængen mellem frigjort seksualitet og demokrati.

Peter: Der tror jeg, at jeg ligger lidt anderledes end jer. Jeg skrev en kronik i Politiken, hvor jeg hyldede det danske frisind. Jeg synes, det er sådan en dejlig historie. Jeg synes, det er en af de der historier, vi skal holde fast i. Jeg tror, man skal passe meget på med ikke at slå den historie ihjel, fordi man kan se, at der er nogle sprækker i den og ting, som måske ikke helt passer. Jeg tror tværtimod, at man skal holde fast i frisind og blive ved med at snakke frisind. Jo mere vi siger det, jo mere tror, jeg det kommer til at passe.

Maja: Det svarer lidt for mig til at diskutere, om Gud nu er god eller ond med en ateist. Jeg taler slet ikke om, hvorvidt der er et dansk frisind eller ej-om vi er mere undertrykte, end vi tror. Jeg taler om, at det at sætte seksualiteten ind $\mathrm{i}$ en historie om frisind eller ej, frisind eller undertrykkelse, frisind eller bornerthed, i sig selv er det, der begrænser vores fortællinger. Det er ikke et spørgsmål om, hvorvidt der er et frisind eller ej. Det er et spørgsmål om, hvorvidt der findes nogle andre historier at fortælle om seksualitet, der ikke skal plottes ind på frisindets fortælling. Det er et spørgsmål om, hvorvidt det overhovedet er en meningsfuld kategori at bruge om seksualitet. Er frisindshistorien ikke en del af repressionshypotesen - "seksualiteten har været undertrykt, nu er vi frie og ikke bornerte mere".

Lene: Det er da klart, at jeg synes, at der er nogle positive ting ved den dominerende frisindskonstruktion, men jeg synes også, der er store problemer ved den. Der er jo både in- og eksklusionsprocesser, der genereres omkring denne her konstruktion, og jeg tror for så vidt ikke, at vi gør frisindet nogen tjeneste ved ikke at kritisere den.

Maja: Det er måske nok magtanalytikerens vigtigste pointe - at etablere en modfortxlling til fortællingen om det danske frisind består ikke $\mathrm{i}$ at sige, at tingene er blevet værre og værre. Det, synes jeg, er ret vigtigt at få med, og det, synes jeg, måske er det, der kendetegner den magtkritiske seksualitetsforskning - at det ikke er spørgsmålet om, at vi skal valge imellem en historie om, at det er blevet bedre og bedre eller en historie om, at det er blevet værre og værre. Men med Foucault kan vi faktisk fortælle en historie om, at frisind og frigørelse og magt ikke er to modsatrettede historier. Det er historier, der trækker i samme ret- 
ning. Det er selve ideen om, at vi kun kan fortælle enten historien om større frigørelse eller større undertrykkelse, der er det undertrykkende. Men man kunne også gøre noget andet. Det er for mig noget af det vigtigste ved det, som Foucault har sat på dagsordenen, at man kan fortxlle denne her historie som noget andet end kampen mellem den undertrykte seksualitet og den frigjorte seksualitet eller kampen mellem magten og friheden. Det skaber en helt anden måde at stille de her spørgsmål på. $\mathrm{Og}$ den kamp, som vi skal se på, er ikke et spørgsmål om frigørelse eller undertrykkelse, men f.eks. hvad er det for et Andet, som det danske frisind per definition etablerer hvad er det, der ikke er dansk og hvad er det, der ikke er frisind og hvorfor hænger de to ting overhovedet sammen. Det er de andre, som den type fortxllinger konstruerer, som er interessante at se på, og som gør, at seksualitet og sådan noget som 'etniskhed' ikke kan skilles ad i vore dage.

Lene: Hvad er det for nogle illegitime seksualiteter, der produceres i gennem frisindet? Her kommer f.eks. de etniske minoriteter i klemme i de her år, for de lever ikke op til det danske frisind.

Maja: Og hvis de gør, underminerer de hele ideen om, at der er et særlig dansk frisind, så derfor skal de helst ikke kunne det, vel.

Peter: Man kan jo udvide den historie. Den er jo ikke banal. Historien om det danske frisind har jo lige så mange udgaver, som der er mennesker i Danmark, og som der er fortællere. Et af grundelementerne er, at vi her i Danmark har det syn på andre, at de kan gøre, hvad de har lyst til, og vi går ikke med en løftet pegefinger. Man kan udvide det danske frisind til også at omfatte etniske minoriteter, at der er flere måder at leve på i Danmark, at der ikke kun er en rigtig måde. Det er jo også en del af historien om frisindet, og derfor synes jeg, det er sådan en god historie. Man kan bruge den til mange ting. Jeg er helt enig i, at selvfølgelig skal den kritiseres, selvfølgelig skal man undersøge den. Vi skal ikke fortælle den så mange gange og så højt, at vi til sidst tror, at det er den eneste historie, der er at fortælle. Men jeg tror, vi skal passe på, at vi ikke slår så hårdt på den, at den dør.

Maja: Men hvis det er en historie, der producerer nogle helt bestemte forskningsresultater og nogle helt bestemte historier om, hvad seksualitet er, så tror jeg, det er godt at lægge den i kisten og så begynde at stille nogle nye spørgsmål i stedet for at stille spørgsmål, der skal placere forskellige køn og etniciteter og klasser på forskellige steder på den seksuelle frigørelseslinje og på det danske frisinds scene. Så vil jeg hellere lægge den død og begynde at stille nogle nye spørgsmål om noget andet end, om vi f.eks. kan inkludere andre i det danske frisind. Der er aldrig noget, der har været så hierarkiskabende som inklusion. Inklusion er en af de mest hierarkiskabende mekanismer, og den vil jeg meget gerne forholde mig kritisk til.

Lene: Og kommer den inklusion til at afhænge af assimilation til normen, til en bestemt frisindsnorm. Så er vi lige vidt på en eller anden måde.

Maja: Inklusion stiller aldrig spørgsmålstegn til normen. Og det må være en af de magtkritiske erkendelser, der er hos Foucault i Seksualitetens Historie, som måske er mere vigtig end sex er - spørgsmålet om magt.

\section{STRATEGIER, POSITIONERINGER OG IDENTITETER}

Spørgsmål fra salen: Der er punkter, hvor I adskiller jer, men føler I også, at I er fagligt beslægtet? 
Maja: Jeg føler større tilhørsforhold til Peter, end jeg ikke gør. Men det er helt klart, at der er nogle ret grundlæggende forskelle på vores tilgang, fordi vi har en faglig forskellighed. Peter er historiker, og det er jeg ikke. Vi har helt klart nogle forskellige objekter, men også forskellige tilgange. Vi stiller nogle forskellige spørgsmål og făr også nogle forskellige svar ud af det. Det er jo sådan, det er med forskning. Da jeg lavede Begreb om Begar, brugte jeg meget de dele af Sedgwick, som jeg kan høre, Peter også bruger, så der ville det være oplagt for os at diskutere Sedgwick. Så er der nogle punkter, hvor vi nok ikke er så ens, og det er de samtidsanalytiske magtkritiske narrativer, hvor vi nok er ret forskellige. Der har jeg måske mere til fælles med en postkolonial inspiration, som Lene også deler, hvor det postkoloniale har mere at gøre med min måde at bruge queer teori på end den historiske måde har. Jeg tror nok først og fremmest, at der, hvor Peter og jeg har mest fight, er, at jeg fornemmer en form for identitetstænkning i Peters projekt. Jeg ville nok ikke kunne gå til "Den Homoseksuelle", ikke i en samtidsanalyse. Det skal man måske lave historiske analyser for at gøre. Jeg tror, det er blevet for diffus en kategori. Det er måske forskellen på historikeren og ikke-historikeren.

Peter: Det er jeg fuldstændig enig i. Den Homoseksuelle er en alt for diffus kategori i dag til, at man kan bruge den til særlig meget. Egentlig også hvis man ser tilbage $\mathrm{i}$ tiden, så forventer man at finde den der så må Den Homoseksuelle være der, den krystalklare Homoseksuelle. Og så bliver det bare splittet op i masturbatører og pædofile og onanister og mærkelige mennesker. Og det er selvfølgelig en meget simplificeret måde at sige det på, men Den Homoseksuelle er sådan et underligt samlebegreb. Man prøver at indhegne noget, der ikke lader sig indhegne. Der er vi egentlig helt på linje.
Maja: Det er rigtigt, at vi kan påtage os seksuelle identiteter og kønsidentiteter, men vi bliver jo også i høj grad pålagt dem, og det er selve den proces, der pålægger os identiteter, der er mit forskningsområde, og hvordan det i en ideel verden ville være et valg, men som i høj grad er noget, som vi er tvunget til. Jeg tror nogle af os, der laver noget, der har med seksualitetsforskning at gøre, føler os mere og mere inspireret af de subkulturelle aktivistiske miljøer. Der sker også nogle ting uden for akademia i de her år, som er ekstremt vigtige. Det har der selvfølgelig altid gjort. Vi kan alle sammen fortælle ACT UP historien, men der sker også ting lokalt, der gør, at der kommer nogle nye bevægelser med nogle nye tanker. Alene det at vi her i København kan mønstre et feministisk folkekøkken af unge feminister under 20, der kan mønstre 50 mennesker, mænd og kvinder, betyder, at der er en helt anden tilgang til kønsforskning, feminisme og seksualitet, end der har været før. Og noget af den inspiration kommer ikke nødvendigvis fra akademia, men kan også komme alle mulige andre steder fra og kan være del af alle mulige andre bevægelser, der også har klasse og etnicitet og alle mulige andre politiske dagsordener, end det der har med køn og seksualitet at gøre.

Bente: Med hensyn til identitetspolitik så er det jo noget af det, som 90'erne meget spændende har problematiseret i forhold til 70'erne og 80'erne. Både feministiske bevægelser og seksualpolitiske bevægelser. Men når man ser historisk på det, så kan man jo godt bruge identitetspolitikken, ikke politisk men analytisk ved at se på, hvordan en gruppe er blevet til en gruppe og stiller nogle krav. Og det gælder både kvinder og homoseksuelle. Når man er historiker, så bliver man på det niveau identitetspolitisk. Men det behøver ikke at betyde, at man ikke i dag kan dekonstruere identiteterne. Jeg har som historiker jo også forsøgt at se, hvordan kvinder bliver subjekter 
og hvordan de begynder at stille krav. Det er jo et identitetspolitisk projekt, men det tilhører jo også fortiden, og jeg mener ikke, man behøver at købe hele pakken, fordi man kigger på den proces og den udvikling.
Tak til

Maja Bissenbakker Frederiksen

Lene Myong Petersen

Peter Edelberg

Bente Rosenbeck

Mathias Danholt 


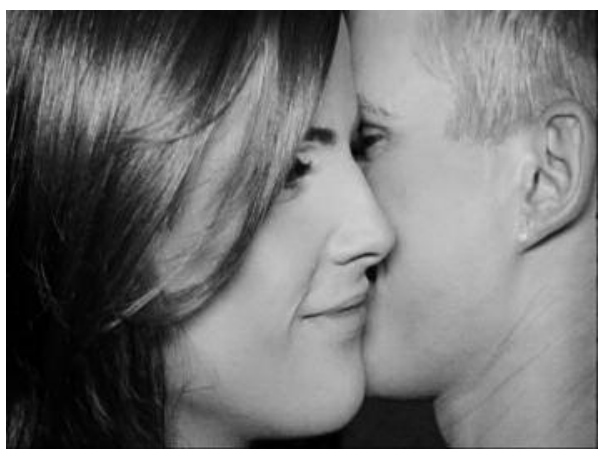

Fra musikvideoen til Thomas Dybdahls sang Dice. Produceret og instrueret af Margreth Olin, Speranza Film AS. 